\title{
Differences in HLA antigens between patients with mixed connective tissue disease and systemic lupus erythematosus
}

Department of Medical Microbiology, University of Oulu, Oulu,

Finland

P Ruuska

R Mäkitalo

J Ilonen

A Tiilikainen

Department of Medicine, Päivärinne Hospital, Jokirinne,

Finland

R Hämeenkorpi

Department of Medicine, North Carelian Central Hospital,

Joensuu,

Finland

$S$ Forsberg

Fourth Department of Medicine, Helsinki University Central Hospital, Helsinki,

Finland

H Julkunen

National Public

Health Institute,

Oulu,

Finland

J Ilonen

Correspondence to: Dr Pekka Ruuska, Department of Medical Microbiology, University of Oulu, Kajaanintie 46E, SF-90220 Oulu, Finland.

Accepted for publication 9 November 1990

Pekka Ruuska, Risto Hämeenkorpi, Sinikka Forsberg, Heikki Julkunen, Reino Mäkitalo, Jorma Ilonen, Anja Tiilikainen

\begin{abstract}
Patients with mixed connective tissue disease (MCTD, $n=32$ ) or systemic lupus erythematosus (SLE, $n=60$ ) were typed for HLA-A, B, C, Dw, and DR antigens. All patients with SLE fulfilled at least four criteria of SLE and the patients with MCTD met the criteria proposed by Alarcon-Segovia (1989). The presence of antibodies to $\mathrm{Sm}$ was not considered as an exclusion for MCTD. In the patients with SLE, Dw3, DR3, and the associated B8 and Al antigens were increased, whereas in the patients with MCTD an increased frequency of Dw4 was found (45 $v 18 \%$ in controls $v 14 \%$ in SLE). Of the subtypes of DR4, Dw4 was present in all but one of the DR4 positive patients. The frequency of DR4 in patients with MCTD (52\%) differed significantly from that of controls $(28 \%)$. The strong association of MCTD to one DR4 subtype was further seen in the significantly increased frequency of the B15, DR4 combination. Thus the genetic background seems to be different in patients with MCTD from that in patients with SLE. This could partly explain the clinical differences between these diseases.
\end{abstract}

Mixed connective tissue disease (MCTD) has been suggested to be a distinct clinical entity. ${ }^{1}$ Hallmarks of this disease are overlapping clinical signs, the absence of or only mild renal disease, and high titres of antibodies to nuclear ribonucleoprotein antigen (anti-RNP). There has been some disagreement on the differentiation of MCTD from systemic lupus erythematosus (SLE). ${ }^{2}$ There are no specific diagnostic criteria for MCTD and many of the patients could easily be diagnosed as having SLE with antiRNP. Alarcon-Segovia ${ }^{3}$ proposed some criteria for MCTD in 1982 and re-evaluated them in $1989,{ }^{4}$ when antibodies to $\mathrm{Sm}$ were accepted in MCTD. MCTD could be a subset of SLE meeting certain criteria for diagnosis and having a typical prognosis, but a classification scheme for this subset is still obscure. ${ }^{5}$

Autoimmune disorders are divided into subgroups by clinical, serological, and genetic factors. Genetic rules can be the most powerful elements determining the type and course of the disease in each patient. The disease associations of the products of the major histocompatibility complex have been studied extensively. HLAA1, B8, DR2 and/or DR3 are associated with SLE ${ }^{6-17}$ and, interestingly, DR2 and DR3 with some autoantibodies appear in SLE and in other autoimmune diseases. ${ }^{5-8} 10141518$

Studies on the HLA associations of MCTD are few and not very convincing. ${ }^{19}{ }^{20} \mathrm{~A}$ couple of reports have linked HLA-DR4 to anti-RNP but not to MCTD itself. ${ }^{621}$ In this work we measured HLA antigens in patients with MCTD and SLE to see if genetic differences between these two diseases could be seen.

\section{Materials and methods}

\section{PATIENTS AND CONTROLS}

We studied a total of 60 patients with SLE and 32 with MCTD. The patients were admitted to three Finnish rheumatology clinics between November 1982 and the end of May 1987 and were examined thoroughly following a predetermined checklist. The diagnosis of each patient was confirmed by two rheumatologists and was re-evaluated at the end of the study if necessary. For a diagnosis of SLE, at least four of the 1982 revised criteria ${ }^{22}$ had to be fulfilled; the clinical and laboratory criteria proposed by Alarcon-Segovia ${ }^{3}$ (table 1) were used for a diagnosis of MCTD. Table 2 lists the characteristics of the patients with MCTD. The presence of antibody to $\mathrm{Sm}$ did not exclude MCTD in this study. ${ }^{4}$ The control group consisted of 270 healthy untreated blood donors and laboratory staff.

\section{HLA TYPING}

HLA-A, B, and C antigens from 32 patients with MCTD and 60 patients with SLE were determined with a standard microlymphocytotoxicity method. ${ }^{23}$ HLA-D typing (22 patients with MCTD and 51 with SLE) was performed with a panel of local homozygous typing cells for Dw1-Dw4 and Dw14 antigens. ${ }^{24}$ HLA-DR typing of 26 patients with MCTD and 48 with SLE was performed in parallel on three commercial typing trays following the instructions of the manufacturers (One Lambda, Los Angeles, CA, USA; Fresenius, Oberursel, Germany; Behringwerke, Marburg, Germany).

Table 1 Clinical and laboratory criteria for the diagnosis of mixed connective tissue disease, as classified by AlarconSegovia $a^{3}$

\footnotetext{
1 Manifestations considered characteristic of two or more connective tissue diseases

2 Three or more* of the following signs or symptoms definitely present:

Oedema of the hands

Raynaud's phenomenon

Scleroderma
}

Arthritis

3 Antibodies to RNP at a haemagglutination titre greater than $1: 1600$, negative or not higher than $1: 160$ with ribonuclease treated extractable nuclear antigen

*If the first three symptoms are present, one of the other two is also required. 
Table 2 Characteristics of patients with mixed connective tissue disease with high titres of antibodies to extractable nuclear antigens; titre of antibodies to extractable nuclear antigen and double stranded DNA and clinical findings used as criteria for the diagnosis of $M C T D$

\begin{tabular}{|c|c|c|c|c|c|c|c|}
\hline \multirow{2}{*}{$\begin{array}{l}\text { Patient } \\
\text { No }\end{array}$} & \multirow[t]{2}{*}{ Sex } & \multicolumn{3}{|c|}{ Antibodies $t^{*}$} & \multicolumn{3}{|c|}{ Clinical findingst } \\
\hline & & ENA & $S m$ & $d s D N A$ & Oedema & Acro & Myo \\
\hline 1 & $\mathbf{F}$ & $\begin{array}{r}81920 \\
\end{array}$ & $\begin{array}{l}0 \\
0\end{array}$ & $\begin{array}{l}0 \\
0\end{array}$ & + & \pm & + \\
\hline 2 & $\underset{M}{F}$ & 163840 & $\begin{array}{l}0 \\
0\end{array}$ & $\begin{array}{l}0 \\
0\end{array}$ & $\begin{array}{l}+ \\
+\end{array}$ & $\bar{t}$ & + \\
\hline $\begin{array}{l}3 \\
4\end{array}$ & $\mathbf{F}$ & $\begin{array}{l}327680 \\
163840\end{array}$ & 0 & $\begin{array}{r}0 \\
160\end{array}$ & $\begin{array}{l}+ \\
+\end{array}$ & $\begin{array}{l}+ \\
-\end{array}$ & $\begin{array}{lll}+ \\
+\end{array}$ \\
\hline 5 & $\mathrm{~F}$ & 40960 & 0 & 0 & + & + & + \\
\hline 6 & $\mathbf{F}$ & 163840 & 0 & 160 & + & - & - \\
\hline 7 & $\mathbf{F}$ & 163840 & 0 & 0 & + & - & - \\
\hline 8 & $\mathbf{F}$ & 5120 & 0 & 0 & + & + & - \\
\hline 9 & $\mathrm{~F}$ & 81920 & 0 & 0 & + & + & - \\
\hline 10 & $\mathbf{F}$ & 327680 & 0 & 0 & + & + & + \\
\hline 11 & $\mathrm{~F}$ & 163840 & 0 & 0 & + & + & - \\
\hline 12 & $\mathbf{F}$ & 327680 & 0 & 0 & + & + & + \\
\hline 13 & $\mathbf{F}$ & 81920 & 0 & 0 & + & - & - \\
\hline 14 & $\mathbf{F}$ & 20480 & 0 & 0 & + & - & - \\
\hline 15 & $\mathbf{F}$ & 163840 & 0 & 0 & + & - & - \\
\hline 16 & $\mathbf{F}$ & 40960 & 0 & 0 & + & - & - \\
\hline 17 & $\mathbf{F}$ & 81920 & 0 & 0 & + & - & - \\
\hline 18 & $\mathbf{F}$ & 327680 & 0 & 40 & + & + & + \\
\hline 19 & $\mathbf{F}$ & 81920 & 0 & 0 & + & - & - \\
\hline 20 & $\mathrm{~F}$ & 163840 & 0 & 0 & + & + & - \\
\hline 21 & $\mathbf{F}$ & 163840 & 0 & 0 & + & - & - \\
\hline 22 & $\mathbf{F}$ & 163840 & 81920 & 1280 & - & + & + \\
\hline 23 & $\mathbf{M}$ & 163840 & 2560 & 0 & + & - & - \\
\hline 24 & $\mathbf{F}$ & 327680 & 81920 & 10240 & - & - & + \\
\hline 25 & $\mathbf{F}$ & 163840 & 1280 & 0 & + & - & + \\
\hline 26 & $\mathbf{F}$ & 327680 & 0 & 0 & + & - & + \\
\hline 27 & $F$ & 655360 & 0 & 0 & + & - & - \\
\hline 28 & $\mathbf{M}$ & 40960 & 0 & 0 & + & - & - \\
\hline 29 & $\mathbf{F}$ & 163840 & 0 & 0 & + & - & + \\
\hline 30 & M & 163840 & 0 & 0 & + & - & + \\
\hline 31 & $M$ & 81920 & 0 & 0 & + & - & - \\
\hline 32 & $\mathbf{F}$ & 81920 & 0 & 0 & + & - & + \\
\hline
\end{tabular}

*The results are expressed as reciprocals of titres. All extractable nuclear antigen haemagglutination positive results were confirmed by the immunodiffusion method. ENA = extractable nuclear antigen; dsDNA=double stranded DNA.

tOedema $=$ oedema of hands, acro $=$ acrosclerosis and $m y 0=$ myositis. Raynaud's syndrome was present in all patients and arthritis in all but patient 26 .

\section{DETERMINATION OF ANTIBODIES TO} EXTRACTABLE NUCLEAR ANTIGEN

Antibodies to extractable nuclear antigen were analysed by passive haemagglutination ${ }^{25}$ and by immunodiffusion. ${ }^{26}$ Ammonium sulphate $(30-60 \%)$ precipitated antigen was elected for

Table 3 Frequencies of the HLA-A,HLA-B and HLA-C antigens which differed between groups and of all typed $H L A-D w$ and $H L A-D R$ antigens

\begin{tabular}{|c|c|c|c|c|c|}
\hline & Controls & $\begin{array}{l}\text { Patients with } \\
\text { MCTD }\end{array}$ & $\begin{array}{l}\text { Patients with } \\
\text { SLE }\end{array}$ & \multicolumn{2}{|l|}{$R R$} \\
\hline & $(\%)$ & $\begin{array}{ll}n & (\%)\end{array}$ & $n$ & MCTD & SLE \\
\hline $\begin{array}{l}\text { Group 1* } \\
\text { HLA-A1 } \\
\text { HLA-A3 } \\
\text { HLA-Aw19 } \\
\text { HLA-B8 } \\
\text { HLA-B16 } \\
\text { HLA-B35 } \\
\text { HLA-Cw4 }\end{array}$ & $\begin{array}{r}40(15) \\
128(47) \\
30 / 268(11) \\
39(14) \\
20(7) \\
78(29) \\
68 / 265(26)\end{array}$ & $\begin{array}{c}5(16) \\
20(63) \dagger^{\mathrm{a}} \\
5(16) \\
6(19) \dagger^{\mathrm{a}} \\
7(22) \dagger^{\mathrm{b}} \\
12(38) \dagger^{\mathrm{a}} \\
12(38) \dagger^{\mathrm{a}}\end{array}$ & $\begin{aligned} 17 & (28) \dagger \\
20 & (33) \\
14 & (23) \dagger \\
27 & (45) \oint \\
5 & (8) \\
7 & (12) \dagger \\
10 & (17)\end{aligned}$ & $\begin{array}{l}1.85 \\
3.50\end{array}$ & $\begin{array}{l}2.27 \\
0.55 \\
2.41 \\
4.85 \\
0.33\end{array}$ \\
\hline $\begin{array}{l}\text { Group 2* } \\
\text { HLA-Dw1 } \\
\text { HLA-Dw2 } \\
\text { HLA-Dw3 } \\
\text { HLA-Dw4 } \\
\text { HLA-Dw14 }\end{array}$ & $\begin{array}{r}70(36) \\
45(23) \\
23(12) \\
34(18) \\
16 / 119(13)\end{array}$ & $\begin{aligned} 5 & (23) \\
3 & (14) \\
5 & (23) \\
10 & (45) \ddagger^{\mathrm{b}} \\
2 & (9)\end{aligned}$ & $\begin{aligned} 8 & (16) \ddagger \\
10 & (20) \\
25 & (49) \oint \\
7 & (14) \\
7 & (14)\end{aligned}$ & 0.51 & $\begin{array}{l}0.32 \\
7.07 \\
0 \cdot 74\end{array}$ \\
\hline $\begin{array}{c}\text { Group 3* } \\
\text { HLA-DR1 } \\
\text { HLA-DR2 } \\
\text { HLA-DR3 } \\
\text { HLA-DR4\| } \\
\text { HLA-DR5 } \\
\text { HLA-DRw6 } \\
\text { HLA-DR7 } \\
\text { HLA-DRw8 }\end{array}$ & $\begin{array}{l}60 / 193(31) \\
46 / 194(24) \\
31 / 192(16) \\
54 / 191(28) \\
18 / 190(9) \\
42 / 194(22) \\
24 / 192(13) \\
34 / 192(18)\end{array}$ & $\begin{aligned} & 5(19) \\
& 4(15) \\
& 6(23)+^{2} \\
& 13(52) \dagger^{+} \mathrm{b} \\
& 1(4) \\
& 5(19) \\
& 0(0) \\
& 8(31)\end{aligned}$ & $\begin{aligned} 8 & (17) \\
11 & (23) \\
25 & (52) \zeta \\
11 & (23) \\
3 & (6) \\
9 & (19) \\
2 & (4) \\
11 & (23)\end{aligned}$ & 0.53 & $\begin{array}{l}0.44 \\
5.65\end{array}$ \\
\hline
\end{tabular}

Abbreviations: MCTD=mixed connective tissue disease; SLE=systemic lupus erythematosus; $\mathbf{R R}=$ relative risk.

${ }^{*}$ Number of subjects: Group 1, controls 270, MCTD 32, SLE 60; Group 2, controls 192, MCTD 22, SLE 51; Group 3, controls 192, MCTD 26, SLE 48.

tp $<0.05$.

$\neq \mathrm{p}<0.01$.

for $M$ MCTD $=25$

In for SLE $=59$.

In for SLE $=59$.

b Differences between MCTD and SLE. immunodiffusion. ${ }^{27}$ Extractable nuclear antigen immunodiffusion was calibrated by reference serum samples for antibodies to Sm, RNP, and SSB, kindly supplied by the AF-CDC ANA reference laboratory (Atlanta, GA, USA). Antigen for haemagglutination was prepared by ethanol precipitation. ${ }^{25}$ Haemagglutination titres after RNAse digestion of extractable nuclear antigen were also recorded. If the titre with digested extractable nuclear antigen was two or more dilution steps lower than in the test without digestion, but not zero, the serum sample was considered to contain both $\mathrm{Sm}$ and RNP antibodies.

\section{ANTIBODIES TO DOUBLE STRANDED DNA}

Antibodies to double stranded DNA were measured by the indirect immunofluorescence method of Aarden et al. ${ }^{28}$

\section{STATISTICAL ANALYSIS}

Statistical analysis of the frequencies of the HLA antigens was performed by $\chi^{2}$ or Fisher's exact test. For comparison, the frequencies in healthy subjects partly published by Partanen $e t$ $a l^{29}$ were applied. Corrected $\mathrm{p}$ values were obtained for the differences in HLA frequencies by multiplying the $p$ values from these tests with the number of specificities tested for in the relevant HLA locus.

\section{Results}

Table 3 shows the frequencies of all DR and Dw antigens determined; the $\mathrm{A}, \mathrm{B}$, and $\mathrm{C}$ specificities which differed between the groups are indicated. 
Table 4 Relative risks of some HLA combinations to mixed connective tissue disease and systemic lupus erythematosus. Results expressed as number positive/ total number of subjects

\begin{tabular}{|c|c|c|c|c|c|c|c|}
\hline \multirow{2}{*}{$\begin{array}{l}\text { HLA antigen } \\
\text { combination }\end{array}$} & \multirow{2}{*}{$\begin{array}{l}\text { Controls } \\
(n)\end{array}$} & \multicolumn{3}{|c|}{$M C T D$} & \multicolumn{3}{|l|}{$S L E$} \\
\hline & & $n$ & $p$ value & $R R$ & $n$ & $p$ value & $R R$ \\
\hline $\begin{array}{l}\text { A1, B8, Dw3 } \\
\text { B8, Dw3 } \\
\text { B8, DR3 } \\
\text { B15, Dw4 } \\
\text { B15, DR4 } \\
\text { B35, Dw1 } \\
\text { B8, B27 } \\
\text { Dw4, DR4 }\end{array}$ & $\begin{array}{r}10 / 179 \\
18 / 179 \\
26 / 191 \\
15 / 178 \\
17 / 189 \\
42 / 179 \\
1 / 270 \\
21 / 130\end{array}$ & $\begin{array}{r}3 / 22 \\
4 / 22 \\
4 / 26 \\
6 / 22 \\
7 / 25 \\
5 / 22 \\
0 / 32 \\
10 / 20\end{array}$ & $\begin{array}{l}\text { NS } \\
\text { NS } \\
\text { NS } \\
0.019 \\
0.013 \\
\text { NS } \\
\text { NS } \\
0.001\end{array}$ & $\begin{array}{l}2.67 \\
1.99 \\
1.15 \\
4.08 \\
3.93 \\
0.96 \\
* \\
5 \cdot 19\end{array}$ & $\begin{array}{r}13 / 51 \\
22 / 51 \\
22 / 48 \\
5 / 51 \\
5 / 48 \\
4 / 50 \\
4 / 60 \\
6 / 43\end{array}$ & $\begin{array}{l}<0.001 \\
<0.001 \\
<0.001 \\
\text { NS } \\
\text { NS } \\
0.027 \\
0.002 \\
\text { NS }\end{array}$ & $\begin{array}{r}5 \cdot 78 \\
6 \cdot 79 \\
5 \cdot 37 \\
1 \cdot 18 \\
1 \cdot 18 \\
0 \cdot 28 \\
19 \cdot 21 \\
0 \cdot 84\end{array}$ \\
\hline
\end{tabular}

Abbreviations: $M C T D=$ mixed connective tissue disease; SLE=systemic lupus erythematosus; $\mathbf{R R}=$ relative risk; $\mathrm{NS}=$ not significant.

${ }^{*}$ Number of mixed connective tissue disease patients with this combination $=0$.

In patients with SLE Dw3 and DR3 were increased with the highest relative risks. Of the antigens associated with these two, B8 was increased very significantly, but the increase in the $\mathrm{Al}$ antigen was less obvious. An increase in Aw 19 and a decrease in B35 and Dwl were also seen.

The group of patients with MCTD clearly differed from those with SLE. The frequencies of DR3 and associated antigens were similar in the control subjects. The HLA-Dw4 antigen was increased, and the frequencies of DR4 and B16 differed significantly from those of control subjects. Ten of the 11 DR4 positive patients with MCTD had Dw4, but only one had Dw14, which is the second MLC defined specificity associated with DR4 which is frequent in Finland. The overall frequency of Dw14 was the same in patients with MCTD and SLE and in control subjects. The association of MCTD with the Dw4 subset of DR4 is also seen in table 4 , in which risks for antigen combinations are presented. The frequencies of several other HLA antigens differed significantly between patients with MCTD and those with SLE: A3, B35, Cw4, Dw4, and DR4 were increased and B8 and DR3 were decreased in patients with MCTD compared with those with SLE.

\section{Discussion}

In this work we analysed types of HLA antigens in 32 patients with MCTD and 60 with SLE to answer two questions: (1) are there any HLA associations with MCTD, and (2) are there genetic differences between patients with MCTD and SLE? The answer to both questions was positive. The frequencies of HLA antigens in MCTD were similar to those in control subjects, with the exception of an increased frequency of HLA-Dw4 (10/22 (45\%) in patients with MCTD, 34/192 (18\%) in control subjects, uncorrected $p=0.006)$. The frequencies of DR4 and B16 were also slightly increased $(p<0.05)$. In both control subjects and patients with SLE the frequency of the Dw4 subtype of DR4 was much lower than it was in patients with MCTD, half of whom carried Dw4.

Previously well known HLA associations with SLE were also seen here. A1, B8, Dw3, and DR3 were increased. ${ }^{6-9} 1112{ }_{16}{ }_{17}$ Dw2 and DR2 frequencies in our patients with SLE were lower than reported previously ${ }^{1013-17}$ and also lower than in our controls. It has been proposed that both DR2 and DR3 antigens might be markers for immune hyper-responsiveness, i.e. increased seroreactivity (anti-Ro, anti-DNA, $\mathrm{RF}$, and hyperglobulinaemia), ${ }^{15}$ thus our patients with SLE would have an antibody pattern different from, for example, American or Japanese series. ${ }^{13}$ Other differences between patients with SLE and control subjects were an increase in the frequency of Aw 19, also reported by Stastny, ${ }^{30}$ and decreases in B35, Dw1, and DR1; these differences were not significant after the correction of $p$ values. The decreases in B35, Dw1, and DR1 antigens (which are very common and occur in one of the most frequent haplotypes in the Finnish population) may be secondary to the increase of the other antigens. Within the well known haplotype A1, B8, Dw3 the highest relative risk for Dw3 supports the proposal that the susceptibility factor to SLE resides in the $D$ end of the HLA region. We could also confirm the previous report ${ }^{31}$ that the combination of B8 and B27 antigens is increased in patients with SLE (relative risk, 19.21), but only a few patients carried this combination.

The association to the Dw4 subtype of DR4 separates patients with MCTD from those with SLE and even from those with rheumatoid arthritis. The Dw4 to Dw14 ratio in patients with MCTD was 10:2 in the whole series (table 3) and 10:1 in DR4 positive patients; the respective values for patients with SLE were 7:7 and 6:5. The increase of the B15, DR4 (Dw4) combination suggests that the susceptibility genes are enriched in one particular haplotype. The two best known disease associations of DR4 (insulin dependent diabetes and rheumatoid arthritis) differ from each other with respect to subtypes. The association of rheumatoid arthritis with DR4 is well documented, ${ }^{32}$ but the proportion of Dw14 is enhanced. ${ }^{33} 34$ In insulin dependent diabetes, the B15, C4A3B3, Dw4, DR4 haplotype gives an excessive relative risk to the disease, although only a fraction of the patients actually have this whole haplotype ${ }^{35}$ It appears that MCTD genetically resembles rheumatoid arthritis and insulin dependent diabetes mellitus more closely than it resembles SLE, which is surprising because the opposite situation is seen clinically. We conclude from these and previously published ${ }^{20}$ results that the susceptibility to MCTD is linked with Dw4. The primary association of HLA antigens might not be with the clinical syndromes themselves but with the autoantibodies found. ${ }^{621}$ The autoantibodies suggested to be associated with HLA include antibodies to SSA (DR3) and RNP (DR4). The association of DR4 with antiRNP has been reported to be very strong, and anti-RNP positive patients with or without MCTD had the same frequency of HLADR4. ${ }^{21}$ We are now trying to determine if the primary association of HLA-Dw4 is with antiRNP or clinical MCTD.

We thank Marja-Leena Hannus, MSc, for performing the HLA typing and Mrs Anitta Kansanniva, Mrs Aino Klemettilä, and Mrs Maija Korkeala for determining antinuclear antibodies. This study was supported by a grant from the Sigrid Juselius Foundation. 
1 Sharp G C, Irvin W S, Tan E M, Gould R G, Holman H R. Mixed connective tissue disease-an apparently distinct rheumatic disease syndrome associated with specific antibody to an extractable nuclear antigen (ENA). Am f Med 1972; 52: 148-59.

2 Reichlin M. Problems in differentiating SLE and mixed connective tissue disease. N Engl F Med 1976; 295: 1194-5.

3 Alarcon-Segovia D. Mixed connective tissue disease: some statements. Clin Rheumatol 1982; 1: 81-3.

4 Alarcon-Segovia D, Cardiel M A. Comparison between 3 diagnostic criteria for mixed connective tissue disease. Study of 593 patients. I R Reumatol 1989; 16: 328-34.

5 Bell D A, Maddison P J. Serologic subsets in systemic lupus erythematosus. An examination of autoantibodies in relationship to clinical features of disease and HLA antigens. Arthritis R heum 1980; 23: 1268-73.

6 Smolen J S, Klippel J H, Penner E, et al. HLA-DR antigens in systemic lupus erythematosus: association with specificity of autoantibody responses to nuclear antigens. Ann Rheum Dis 1987; 46: 457-62.

7 Whittingham S, Mackay I R, Tait B D. Autoantibodies to small nuclear ribonucleoproteins. A strong association between anti-SS-B (La), HLA-B8, and Sjögren's syndrome. Aust NZ F Med 1983; 13: 565-70.

8 Specker C, Lakomek H J, Kuntz B M E, Bremer G, Goerz G, Krüskemper H L. Signifikante assoziation des HLA-B8 zum systemischen lupus erythematosus und zu bestimmten serologischen markern. Disch Med Wochenschr 1987; 112: $577-80$.

9 Stenszky V, Kozma L, Szegedi G, Farid N R. Interplay of immunoglobulin $G$ heavy chain markers $(\mathrm{Gm})$ and HLA in predisposing to systemic lupus nephritis. $\mathcal{f}$ Immunogenet 1986; 13: 11-7.

10 Hochberg M C, Boyd R E, Ahearn J M, et al. Systemic lupus erythematosus: a review of clinico-laboratory features and immunogenetic markers in 150 patients with emphasis on demographic subsets. Medicine (Baltimore) 1985; 64: 285-95.

11 Stenszky V, Kozma L, Szegedi G, Sonkoly I, Bear J C, Farid N R. Heterogeneity of systemic lupus erythematosus elucidated by cluster analysis. The influence of HLA. Immunogenetics 1986; 13: $327-40$.

12 Bell D A, Rigby R, Stiller C R, Clark W F, Harth M, Ebers G. HLA antigens in systemic lupus erythematosus: relationship to disease severity, age at onset, and sex. $\mathcal{I}$ Reumatol 1984; 11: 475-9.

13 Hashimoto $\mathrm{H}$, Tsuda $\mathrm{H}$, Matsumoto T, et al. HLA antigens associated with systemic lupus erythematosus in Japan. f Rheumatol 1985; 12: 919-23.

14 Alvarellos A, Ahearn J M, Provost T T, et al. Relationships of HLA-DR and MT antigens to autoantibody expression in systemic lupus erythematosus. Arthritis Rheum 1984; 27: 1533-5.

15 Ahearn J M, Provost T T, Dorsch C A, Stevens M B, Bias W B, Arnett F C. Interrelationships of HLA-DR, MB, and MT phenotypes, autoantibody expression, and clinical features in systemic lupus erythematosus. Arthritis Rheum 1982; 25: $1031-40$.

16 Tiwari L J, Terasaki P I, eds. Connective tissue disease. In: $H L A$ and disease associations. Berlin: Springer, 1985: 363-78.

17 Reinertsen J L, Klippel J H, Johnson A H, Steinberg A D, Decker J L, Mann D L. B-lymphocyte alloantigens associated with lupus erythematosus. $N$ Engl f Med 1978; 299: 515-8.

18 Manthorpe R, Teppo A M, Bendixen G, Wegelius O. Anti- bodies to SS-B in chronic intlammatory connective tissue disease. Relationship with HLA-Dw2 and HLA-Dw3 antigens in primary Sjögren's syndrome. Arthritis Rheum 1982; 25: 662-7.

19 Sasazuki T, Kaneoka H, Ohta N, Hayase R, Iwamoto I. Common HLA-haplotypes and their association with diseases in the Japanese population. Transplant Proc 1979; 11: $1871-3$.

20 Black C M, Maddison P J, Welsh K I, Bernstein R, Woodrow J C, Pereira R S. HLA and immunoglobulin allotypes in mixed connective tissue disease. Arthritis Rheum 1988; 31: $131-4$.

21 Genth E, Zarnowski H, Mierau R, Wohltmann D, Hartl P W. HLA-DR4 and Gm $(1,3 ; 5,21)$ are associated with U1-nRNP antibody positive connective tissue disease. Ann Rheum Dis 1987; 46: $189-96$.

22 Tan E M, Cohen A S, Fries J F, et al. The 1982 revised criteria for the classification of systemic lupus erythematosus. Arthritis Rheum 1982; 25: 1271-7.

23 Turunen O, Lundqvist C, Julin M, Holmlund G, Tiilikainen A, De la Chapelle A. Stimulatory and cytotoxic activity on human adult and fetal lymphocytes by heterologous antihuman fetal lymphocyte sera. Transplant Proc 1979; 27: human.

24 Ilonen J, Lagerstedt A, Koskimies S, Reunanen $M$. HLA-Dwl and BfF as protective markers in multiple sclerosis. I Neuroimmunol 1983; 5: 283-8.

25 Nakamura R M, Peebles C L, Tan E M. Microhemagglutination test for detection of antibodies to nuclear Sm and ribonucleoprotein antigens in systemic lupus erythematosus ribonucleoprotein antigens in systemic lupus erythematosus

26 Dorsch C A, White $G M$, Berzofsky $R$ N. The measurement of antibodies to extractable nuclear antigen. Am $\mathcal{F}$ Clin Pathol 1979; 71: 333-7.

27 Venables P J W, Charles P J, Buchanan R R C, et al. Quantitation and detection of isotypes of anti-SS-B antibodies by ELISA and Farr assays using affinity purified antigens. An approach to the investigation of Siögren's syndrome and systemic lupus erythematosus. Arthritis Rheum 1983; 26: 146-55.

28 Aarden L A, deGroot E R, Feltkamp T E W. Immunology of DNA. III. Crithidiae luciliae, a simple substrate for the determination of anti-dsDNA with the immunofluorescent technique. Ann N Y Acad Sci 1975; 254: 505-15.

29 Partanen J, Koskimies S, Ilonen J, Knip M. HLA antigens and complotypes in insulin-dependent diabetes mellitus. Tissue Antigens 1986; 27: 291-7.

30 Stastny P. The distribution of HLA-A antigens in black patients with systemic lupus erythematosus (SLE). Abstract. Arthritis Rheum 1972; 15: 455-6.

31 Whittingham S, Mathews J D, Schanfield M S, Tait B D, Mackay I R. HLA and Gm genes in systemic lupus erythematosus. Tissue Antigens 1983; 21 : 50-7.

32 Tiwari L J, Terasaki P I, eds. Rheumatology and joint diseases. In: HLA and disease associations. Berlin: SpringerVerlag, 1985: 363-78.

33 Nepom G T, Seyfried C E, Holbeck $S$ L, Wilske $K$ R, Nepom B S. Identification of HLA-Dw14 genes in DR4+ rheumatoid artiritis. Lancet 1986; ii: 1002-5.

34 Hakala $M$, van Assendelft A H W, Ilonen J, Jalava $S$, Tiilikainen A. HLA antigens Dw4 and Dw 14 in rheumatoid arthritis. Ann Rheum Dis 1987; 46: 492-3.

35 Ilonen J, Surcel H M, Partanen J, Koskimies S, Knip M, Käar M L. Extended HLA haplotypes in families with insulin-dependent diabetes mellitus in northern Finland. Tissue Antigens 1988; 32: 139-44. 